\title{
EWSR1/ETV4 Fusion Gene
}

National Cancer Institute

\section{Source}

National Cancer Institute. EWSR1/ETV4 Fusion Gene. NCI Thesaurus. Code C99262.

A fusion gene $(\sim 2.1 \mathrm{~kb})$ that results from a chromosomal translocation $\mathrm{t}(17 ; 22)(\mathrm{q} 21 ; \mathrm{q} 12)$

which fuses the first seven exons of the EWSR1 gene to the last 6 exons of the ETV4 gene. This rearrangement is associated with Ewing sarcoma. 